\title{
Semantic change and intersubjectification: The origin of reprise evidential conditional in Old Catalan
}

\author{
Josep Martines \\ Universitat d'Alacant. ISIC-IVITRA \\ josep.martines@ua.es
}

Received: July 23, 2015

Accepted: August 6, 2015

\begin{abstract}
The reprise evidential conditional (REC) is nowadays not very usual in Catalan: it is restricted to journalistic language and to some very formal genres (such as academic or legal language), it is not present in spontaneous discourse. On the one hand, it has been described among the rather new modality values of the conditional. On the other, the normative tradition tended to reject it for being a gallicism, or to describe it as an unsuitable neologism. Thanks to the extraction from text corpora, we surprisingly find this REC in Catalan from the beginning of the fourteenth century to the contemporary age, with semantic and pragmatic nuances and different evidence of grammaticalization.

Due to the current interest in evidentiality, the REC has been widely studied in French, Italian and Portuguese, focusing mainly on its contemporary uses and not so intensively on the diachronic process that could explain the origin of this value. In line with this research, that we initiated studying the epistemic and evidential future in Catalan, our aim is to describe: $a$ ) the pragmatic context that could have been the initial point of the REC in the thirteenth century, before we find indisputable attestations of this use; $b$ ) the path of semantic change followed by the conditional from a 'future in the past' tense to the acquisition of epistemic and evidential values; and c) the role played by invited inferences, subjectification and intersubjectification in this change.
\end{abstract}

Keywords: reprise evidential conditional; evidentiality; semantic change; subjectification; intersubjectification; corpus linguistics; diachronic cognitive semantics; pragmatics.

* This work was prepared at the Institut Superior d'Investigació Cooperativa IVITRA [ISICIVITRA] of the Generalitat Valenciana (Programa de la Generalitat Valenciana per a la Constitució i Acreditació d'Instituts Superiors d'Investigació Cooperativa d'Excel·lència [Ref. ISIC/012/042]), within the following research projects: «Gramàtica del Català Modern (1601-1834)» (MINECO, Ref. FFI2012-37103); «Constitució d'un corpus textual per a una gramàtica del català modern $(\mathrm{Gcm}) »$ (IEC [PT 2012-S04-MARTINES]); Digicotracam (Programa PROMETEU per a Grups d'Investigació en I+D d'Excel·lència, Generalitat Valenciana [Ref.: PROMETEO-2014-018], financed by FEDER of the EU; and «Grup d'Investigació en Tecnologia Educativa en Història de la Cultura, Diacronia lingüística i Traducció» (Universitat d'Alacant [Ref. GITE-09009-UA]). 
Resum. Canvi semàntic i intersubjectivització: l'origen del condicional evidencial de report en català antic

El condicional evidencial de report (CER) no és gaire habitual en català: està restringit al llenguatge periodístic i a alguns registres molt formals (com el llenguatge acadèmic o el legal) i no es troba en el discurs espontani. D'una banda, s'ha descrit entre els nous valors modals del condicional. De l'altra, la normativa l'ha rebutjat com a gal-licisme o com neologisme inapropiat. Mitjançant l'anàlisi de corpus textuals, hem documentat el CER en català des dels inicis del segle XIV a l'actualitat, amb matisos semàntics i pragmàtics i diferents graus de gramaticalització.

A causa de l'actual interès en l'evidencialitat, el CER s'ha estudiat a fons en francès, italià i portuguès, però centrant-se principalment en els seus usos contemporanis i no de manera tan detallada en el procés diacrònic que ens podria explicar aquests usos. Seguint aquesta línia de recerca, que van començar amb l'estudi del futur epistèmic i evidencial en català, tenim per objectiu descriure: a) el context pragmàtic que hauria estat el punt de partida del CER en el segle XIII, abans de trobar documentat aquest ús; $b$ ) el procés de canvi semàntic seguit pel condicional des d'un 'futur del passat' a l'adquisició de valors epistèmics i evidencials i $c$ ) el paper que tenen les inferències, la subjectificació i la intersubjectificació en aquest procés de canvi.

Paraules clau: condicional evidencial de report; evidencialitat; canvi semàntic, subjectificació; intersubjectificació; lingüística de corpus; semàntica cognitiva; pragmàtica.

\section{Table of Contents}

\section{Introduction}

2. Subjectification of the future and of the future-of-the-past
3. Intersubjectification of the future and the future-of-the-past: the path to REC

4. Conclusions

References

\section{Introduction}

It might not be an exaggeration to speak of a novelty, or even a surprise, of the fact that in Old Catalan we have found, with remarkable frequency, evidence of something we will henceforth call reprise evidential conditional (REC). This phenomenon is to be found since, at least, the beginning of the fourteenth century and up until the Modern Age, without there being an interruption in its use. With no claims of exhaustiveness, and merely as an illustration, let us consider the following samples that display varying degrees of grammaticalization, textual typology and semantic nuances:

(1) a poc de dies ageren ardit com don Pedro per cert auria pres lo dit castell (Cartes Jaume II, 1310, 391)

[a few days ago they had received notice that Don Pedro would have taken over said Castle $]^{1}$

1. Our translation of the cited examples aims to provide a literal correspondence with the original. Frequent abbreviations used in this article: $a / b$ (after a given century) 'first or second half of the century'; AD/R 'addressee/reader'; C 'conditional'; c. 'circa'; EpC 'epistemic conditional; EpF 
(2) Pervench a-audiència dels molt honorables en Ramon de Canet [...] que Ffrancí Coll [...] serie alcavot públic e haurie tenguda fembra en lo bordell públicament, e serie viscut de son mal guany (Processos de Lleida, 1438, 39) [It reached the ears of the Most Honorable Ramon de Carnet [...] that Francí Coll [...] would be a public whoremonger and would have taken a woman publicly at a brothel, and would have lived off of this unwholesome business]

(3) Entés havem que en aqueix loch se trobaria hun malalt de llebrosia (Epistolari de València II, 1463, 372)

[We have heard that a leper would be in that place]

(4) car yo veig açí venir en la cort del senyor rey embaixadors del papa per contractar matrimoni de son nebot, que volen dir alguns seria fill, ab vostra altesa (Martorell, Tirant, 1460, 383)

[because here I see ambassadors of the pope coming to the court of the master king to pact his nephew's marriage, who some say would be his son, with His Highness]

(5) Diu-se que ell y lo bisbe de Tortosa serian morts de pació de ànimo de las turbulèncias que corren en Barcelona (Pujades, Dietari, III, 1622, 122)

[It is said that he and the Bishop of Tortosa would have died of a mood's passion because of the turbulence that runs through Barcelona]

(6) lo qual [Cortada] és estat capturat per lo batlla de Castelltersol [...] ab lo motiu de què lo hauria trobat ab pistolas [...]. Y al cap de dos días [...], ha constat a sas senyorias que dit Cortada estava en lliberat y que se li haurian restituhit las ditas armas. (Dietaris de la Generalitat de Catalunya, x, 1701, 4b-5a) [which citizen [Cortada] has been captured by an officer of justice of Castellterçol [...] under charges that they would have found him in possession of guns $[. .$.$] . And after two days [...], it has been documented that Cortada$ was set free and that his weapons would have been returned]

The novelty and surprise may come both from the age of this use as well as its persistence, and the fact that the REC is nowadays not very usual in Catalan: it is just restricted to journalistic language and to some very formal genres (such as academic or legal language), and it is not present in spontaneous discourse. On the one hand, it has already been described within a set of newer modality values of the conditional. On the other hand, the normative tradition tended to reject it for being a gallicism, or to describe it as an unsuitable neologism, although some scholars have displayed tolerance of its use (Pérez-Saldanya 2002: 2644, n. 59).

'epistemic future'; Ev 'evidential'; F 'future'; FP 'future-of-the-past'; FPC 'future-of-the-past conditional'; REC 'reprise evidential conditional'; SoA 'State of Affairs'; SP/W 'speaker/writer'; $\mathrm{TF}$ 'temporal future'. 
Surprisingly, and thanks to the extraction from text corpora (CIMTAC and CICA), we find this REC in Catalan from the beginning of the fourteenth century to the contemporary age, with semantic and pragmatic nuances and different evidence of grammaticalization.

Although very interesting indeed, we will not engage here in the discussion about the content and limits of the concept of evidentiality («Evidentiality proper is understood as stating the existence of a source of evidence for some information», Aikhenvald 2003: 1). In the past few years, the literature on evidentiality has undergone an accelerated growth; so has its study, both in languages that have evidentiality as a necessary grammatical marking, and in those in which it constitutes a difficult case for application. Already well known and studied is the use of $\mathrm{C}$ as a resource in discourse to mark the source of information in Romance languages such as French, Italian, Portuguese and Spanish (Squartini 2004, 2009, 2010, 2012, Dendale 2014, Rivero 2014). For the purposes at hand, Dendale's (2014: 246) synthetic description of French conditional seems appropriate, which he labels conditionnel de reprise. He lists its three basic, characteristic traits: «(a) le caractère incertain de l'information ou l'incertitude du locuteur; (b) la reprise à autrui de l'information donnée; (c) la non-prise en charge de l'affirmation par le locuteur». This description comes close to that proposed by Pérez-Saldanya (2002: 2644) for certain uses of the conditional «with an evidential value» identified in contemporary Catalan, as previously mentioned: $a$ ) in academic texts (to report on an other's point of view), b) journalistic texts (to indicate that the information provided comes from unverified sources) or, $c$ ) in general, in formal texts (to indicate unconfirmed and unendorsed information). As we can see, these definitions allow therefore an epistemic and an evidential component in this use of the conditional.

This is where we draw attention to the process that may have led to the emergence of the REC in Catalan. If, as previously mentioned, we have discovered that the first written evidence of REC in this language (see (1)) is found at the beginning of the fourteenth century, we must try to find out what developments in the previous century could have led to this value. Due to the current interest in evidentiality, the REC has been widely studied in other Romance languages. However, these studies have focused on its contemporary uses and not so intensively on the diachronic process that could explain the origin of this value. In the line of this research, that we initiated studying the epistemic and evidential future in Catalan (Martines 2015), our aim is to describe: $a$ ) the pragmatic context that could have been the initial point of the REC in the thirteenth century, before we find indisputable attestations of this use (see supra (1-6)); $b$ ) the path of semantic change followed by the conditional from a 'future in the past' tense to the acquisition of epistemic and evidential values; and c) the role played by invited inferences, subjectification and intersubjectification in this change. 


\section{Subjectification of the future and of the future-of-the-past}

It is well known that $\mathrm{F}$ forms in Romance, such as cantaré (Catalan and Spanish), (je) chanterai (French), canterò (Italian), cantarai (Occitan), cantarei (Portuguese), etc. derive from the Latin «Infinitive + HABEŌ» construction. More recent studies, based upon Latin corpora, seem to confirm that this construction must have crystallized in a $\mathrm{F}$ during the early third century, following a process that may provide some nuance to existing accounts of its path:

\section{(7) $1^{\text {st }}$ Ability/capacity (Classic Latin)}

$2^{\text {nd }}$ Ability/capacity, obligation, possibly permission (Post-Classical), and $3^{\text {rd }}$ Ability/capacity, obligation, permission, generalized deontic possibility and necessity, future (Later Latin; mainly Christian authors/works) (Hertzenberg 2012: 374$)^{2}$

It is not until the latter fourth century that «some of the future examples may also be given an epistemic reading», although «no example seems to be unambiguously epistemic» (Hertzenberg 2012: 374-375).

For its part, in its original role as the 'future-of-the-past' (FP; Fleishchman 1982: 59) or 'ultériorité dans le passé' (Thomas 2012), the conditional undergoes a process of approximation to the parallel and synchronous epistemic realm. We may recall that the Romance conditional cantaria (Catalan, Occitan and Portuguese), cantaría (Spanish), (je) chanterais (French), etc. resulted from the grammaticalization of the Latin «Infinitive + HABËBAM» construction, which is a variation of «Infinitive + HABEŌ» in imperfect tense. ${ }^{3}$ These constructions exhibit similar grammaticalizations, as well as similar initial paths of semantic evolution, which go through modal values towards the future (future-of-thepast in the case of «Infinitive + HABËBAM»; see (7)) (Fleishchman 1982: 59; Hertzenberg 2008, 2012; Thomas 2012; Company 2006). ${ }^{4}$ The first evidence of «Infinitive + НАВËBAM» with a future-of-the-past value is found in the first half of the third century, the same period in which «Infinitive + HABEŌ» with a future value is found. Two examples ( $8 \mathrm{a}$ and $8 \mathrm{~b}$ ) belong to different language registers ((8a) more formal/(8b) closer to oral discourse) and have different contexts; (in (8a), the speaker/writer, the author, reports information obtained from a source: 'somebody prophesized that he would be called Nazareus'; and, from the past, places an event at a later point; and, in (8b) the speaker/writer

2. The following outline provides a synthesis of the paths (or itineraries) proposed until now in the literature: 'possession' > 'obligation'/'predestination' > 'intention' > 'future' (Fleischman 1982: 129; Bybee et al. 1994: 240; van der Auwera \& Plugian 1998: 96-97; Pérez-Saldanya 1998; Squartini 2001, 2009; Pietrandrea 2005; Company 2006).

3. Recall the perfect variant «Infinitive + HABUĪ», which originates the Italian canterei (Squartini 1999).

4. During this very same period (fifth century), the first cases of «Infinitive + HABËBAM» as conditional constructions appeared. This is unlikely to be a coincidence. To illustrate, recall a well-known example: «Sanare te habebat Deus per indulgentiam si fatereris» (Sermons. 253. 4; Bourciez, 1910: $\S 257,6$; 'God would heal you by his indulgence, if you confessed'). 
(SP/W; the Evangelist), places an event at an event ulterior to the past recalled in his narrative: 5

(8) a. Nazarenus vocari habebat secundum prophetiam (Tertullian, 210 A.D., Adversus Marcionem 4,8; Slobbe 2004: 114)

[According to the prophecy he would be called Nazareus]

b. misit illos binos ante faciem suam in omnem ciuitatem et loca quo uenire ipse habebat (Gospel of Luke, 10.1, s. II-III; Thomas 2012: 16) ${ }^{6}$

[[Christ] sent them two in two ahead of him to every town and place, where he himself would go]

These antique examples already display the dialogical structure that incorporates the conditional $(\mathrm{C})$. This structure has been recently under scrutiny, as it opens the path for the emergence of values such as those presented here. According to Bres \& Azzopardi \& Sarrazin (2010), and Bres (2014), if the F is an «ultériorité du présent», the $\mathrm{C}$ is an «ultériorité du passé»: the $\mathrm{F}$ sets a point $\mathrm{R}$ at a $\mathrm{t}_{0}$ moment of enunciation, after which a process $\mathrm{P}$ is set at an ulterior time; given that point $\mathrm{R}$ is set at $\mathrm{t}_{0}$, this ulteriority is originated in the locuteur-énonciateur $\mathrm{E}_{1}$ of an utterance E. As a result of its role as FP, things are different for the $\mathrm{C}$ : the locuteur-énonciateur $\mathrm{E}_{1}$ places $\mathrm{R}$ in the past. «L'ultériorité, pour se construire comme monde(s) possible(s) à partir de ce point, demande un autre acte d'énonciation $e$, doté d'un autre énonciateur $e_{1}$ » (Bres 2014: 22). If we regard the early example (8a), the $\mathrm{E}_{1}$ (the narrator or locuteur-enonciateur: $\mathrm{SP} / \mathrm{W}_{\mathrm{L}}$ ) reports the words of $e_{1}$ (the prophecy: $\mathrm{SP} / \mathrm{W}_{\mathrm{S}}$ or locuteur-source), words produced in an utterance $e$, anterior to $\mathrm{E}$.

Sometime during the Early Middle Ages, it is assumed, this modalization process of future and FPC (future-of-the-past conditional) took off from ambiguous contexts in late Latin (fourth or fifth century) We have recently described (Martines 2015) the semantization of Ep values of $F$ forms in Catalan, still in specific contexts and uses, as having taken place no earlier than the late thirteenth century. ${ }^{7}$ What follows $a$ ) is a brief summary of elements in our description which are relevant to understanding the emergence of the EpF in Catalan, and $b$ ) we shall see that this development must have been contemporary with the EpC. As we will show below in $\S 3.2$., the EpC in the thirteenth century had triggered a process of intersubjectification, partly concurrent with the EpF, which must have paved the way for the appearance of REC (though this value was not documented until the fourteenth century).

5. In any case, let us observe that the SP/W in a narrative context is actually reporting known information, as it has been received from oral or written sources.

6. In the Vulgata: «[...] quo erat ipse venturus». For more instances of the same source see Herman (1997: 88) and Company (2006: 356).

7. For a Romance perspective, see Fleischman (1982). Specifically, Jensen (1986: 407, 1990: 351) for French and Occitan; Company (2006: 406), for Spanish; or Brambilla Ageno (1965), Squartini (2001: 200) and Pietrandrea (2005: 198), for Italian. 
After detailed tracking and an analysis based on a text corpus, it was concluded that the emergence of EpF was characterized by subjectification ${ }^{8}$ and gradualness (Brinton \& Traugott 2005: 26). Hopper \& Traugott (1993 [2003]: 42-44) provided an original method of analysis for the study of grammaticalization, since then widely applied. Their work considered the $\mathrm{F}$ in the light of deontic meaning, in the context of the Theory of Grammaticalization, which highlights the relevance of processes of pragmatic inference. This way, they took the French chanterai (< «Infinitive + HABERE»), a) to illustrate a possible reanalysis for (9):

(9) $[$ cantare $]$ habeo $]$ (Classic Latin) $>[$ cantare habeo $]$ (Later Latin) $>[$ chant-e$r$-ai] (French)

This process was very likely aided by contexts in which this construction could be construed as deontic or, at least, oriented towards the F; this way, in a case such as (10), «if one is asked what [one] can say, the inference can be that one ought to say it»:

(10) Et si interrogatus fueris, quomodo dicere habes? Veritatem dicere habeo (Cod. Diplo. Long. Siena, 715 A.D.; taken from Fleischman 1982: 59)

[And you, if you are asked, what do you have to/will you say? I will have the truth to say/I will speak the truth]

And $b$ ) to introduce the role of context-favored inference: «processes of abduction could lead a language user to interpret the input string not as representing two underlying clauses, but rather as bracketed together in a structure of the type [cantare habeo], provided of course that the forms are adjacent» (see (10)).

This kind of analysis, as well as more extensive studies of modal verbs (Traugott \& Dasher 2002), highlight the need for us analysts to return to the text, and to regard its pragmatic conditions for a better understanding of processes of semantic change. On this path, Narrog (2012: 171-184) has revised several basic proposals in the study of modality. Based in part on Bybee et al. (1994: 24-29) and Heine (1995: 126), Narrog identifies one factor of the predictive (non-volitive) component which may be aiding the emergence of EpF; he quotes, among others, the English will ${ }^{9}$ and the German werden, ${ }^{10}$ as well as a reference to the synthetic F in Spanish, nowadays mostly Ep (especially in American Spanish). ${ }^{11}$ Although

8. Subjectification, in the Traugottian sense: «semasiological process whereby SP/Ws come over time to develop meanings for Ls ['lexemes'] that encode or externalize their perspectives and attitudes as constrained by the communicative world of the speech event, rather than by the so-called «realworld» characteristics of the event or situation referred to» (Traugott \& Dasher 2002: 30).

9. Narrog (2012: 171) points out, following Visser (1969) and Aijmer (1985), that will, originally a volitional verb, took up predictive values already in the tenth century, and in the fourteenth and fifteenth centuries, it expressed suppositions, deductions or inferences.

10. The first cases of the F werden (thirteenth century) already include a «modal connotation through which the speaker expressed her or his expectations and inference». From the sixteenth century onwards, it appears with an Ep value and oriented towards the present.

11. More on Ep values of the F in American Spanish, see Sedano (2005), Aaron (2007), Soto (2008), Kornfeld (2014). 
they placed their emphasis on the volitive component as a starting point for the development of Ep in the English will, recall that Traugott \& Dasher (2002: 221224) had already proposed (together with Aijmer 1985) a) that the development of the Ep value of will could have emerged in contexts of use in $2^{\text {nd }}$ and $3^{\text {rd }}$ person, which are more often linked with directive uses and, above all, with prediction, and b) that the change might hence spread to the $1^{\text {st }}$ person, more often related to the expression of volition and intention; this process would stress «the high degree of context-sensitivity of semantic change» (p. 224). De Hann (2010: 111) chooses the label predictive for a use of will in a phrase one may already consider as canonical, given the fact that it has been used (sometimes as a sole example) in various languages to exemplify EpF:

\section{(11) [The doorbell rings] That will be the postman}

Likewise, Narrog (2012: 278) has drawn attention to the relationship between aspect and modality; following Comrie (1976) and Frawley (1992), Narrog conceives of prospective forms as «an aspectual category describing the transition from a current state to some subsequent event, which also has temporal, modal, and evidential features». This way, the English to be about to («Summer in Tokyo is about to get even hotter») presents a) temporal value, which refers to a time posterior to the time of reference, b) modal value, linked to the predictive character of the proposition that has been introduced: the event is predicted and non-factual, and c) evidential value, given that said prediction «is usually based on some kind of evidence». The F, in connection with the prospective aspect, takes on subjective Ep values, in various languages, as had been already noted in Bybee et al. (1994); Narrog (2012: 280) observes this occurring for the English will, and considers the following itinerary as a plausible description: 'prospective' $>$ ' $F$ ' $>$ 'probability'. Pérez-Saldanya (2002: 2597-2598) had already emphasized that prospective forms ( $\mathrm{F}$ and $\mathrm{C}$ ), as well as others in the past, may adopt modal values in Catalan or, at least, in some of its varieties; in fact, this work places F and $\mathrm{C}$ among the verbal tenses which are most closely related to modality.

All in all, from a diachronic perspective, it seems viable to suggest that the predictive role of $\mathrm{F}$ and its prospective aspect might pave the way for the development of the Ep value. Above all, as has been shown in Martines (2015), from contexts in which modal and evidential values take prevalence, and temporal values are weakened, or even absent. Along these lines, Langacker's (2003) hypothesis of extreme subjectification may serve to add another essential characteristic to the semantization of Ep. Its tendency to always evolve towards a more subjective and, eventually, intersubjective orientation (in the terms suggested by Traugott \& Dasher 2002, Traugott 2003) or «more speech act orientation» (in terms of Narrog 2012: 183), makes it possible to relate the origin of the Ep value of $F$ to inference and subjectification, in a langackerian sense: ${ }^{12}$

12. As we know, Langacker's subjectification concept does not correspond with that applied by Traugott, which we apply here; but, in this case, it does help to understand the process. 
While the future-oriented use reflects a projection of reality, or the presumed development of things in the outside world, an inference about the present is more internal to the speaker's reasoning. (Narrog 2012: 183)

The usage as present of forms originally oriented towards the F, involves (Langacker 2003: 13 and 15) «a subtle kind of subjectification, above and beyond the high degree of subjectification already implied in a future use»: for the usage as present of $\mathrm{F}$ forms, «evolution of the world out there is not at issue [...] The only thing conceived as evolving is what the speaker supposedly knows, i. e. reality as a mental construct».

In an approach related to ours, Morencey (2010), Saussure \& Morencey (2012), and Saussure (2013) have emphasized that the acquisition of an Ep value for $\mathrm{F}$ does not depend as much on its modal nature, metaphysically related to uncertainty and hypothesis, or on the pragmatic «game» it can allow. Instead, they propose a process of pragmatic enrichissement, close to the one proposed by Hopper \& Traugott (1993 [2003]: 92) and, as we will see below, a linkage between the EpF and the future verification of a possible state of affairs (SoA); in other words, they propose «an allocentric representation» ('a representation which is attributed to somebody other than the SP/W at the moment of utterance', Saussure \& Morencey 2012: 209).

The Invited Inference Theory of Semantic Change (IITSC; Traugott \& Könnig 1991), based on the conventionalization of conversational implicatures and on the progressive subjectification of meaning, has been embraced by Pietrandrea (2005: 200-202) to attempt an explanation of the origin of EpF in Italian. It begins with an hypothesis on the emergence of the epistemic value of must in English, according to which «if a speaker believes that a state of affairs is obligatory he invites us to infer that he believes that that state of affairs is true», to ascertain that the EpF, «like the temporal future, expresses a prediction, which rather than concerning a state of affairs, concerns the truth of the proposition describing that state of affairs». This would explain the reanalysis of constructions of $\mathrm{F}>\mathrm{EpF}$ : [Fut $\left.\left.(\mathrm{SoA})_{\text {pred }}\right]_{\text {prop }}\right] \rightarrow$ Fut $\left.\left[(\mathrm{SoA}){ }_{\text {pred }}\right]_{\text {prop }}\right]$.

This picture is congruent with $a$ ) the notion of itineraries (see (7) and note 2) and of a gradual process in the emergence of values derived from F (or from FP), concretely the Ep, and $b$ ) the need to pay attention to texts, their typology and chronology in tracing such itineraries; it seems, for instance, that EpF (or EpC) have not existed always, not even with the same values (at least in Catalan), contrary to other suggestions (at least regarding other Romance languages). c) With the importance of keeping in mind the temporal, modal and evidential components of $\mathrm{F}$, and non-volitive usage. d) With the notion that pragmatic enrichment and projection towards the $\mathrm{F}$ of prediction, at least with some of its uses. And $e$ ) with the IITSC (Traugott \& Dashier 2002, Traugott 2012; for Catalan Cuenca \& Massip 2005, Martines 2013; Martines \& Montserrat 2014, Martines in press); the main fact - the use of a F form to express the present with an Ep value - can be explained without an appeal to the nature of a $\mathrm{F}$ that is metaphysically linked to the unknown and hypothetical. 
Taking into account this brief description, we may conjecture the incidence and interaction of the following invited inferences (inferences stimulated by the communicative context), here briefly referred to; they involve the bleaching of the temporal element of F (or FP) and the strengthening of the modal and evidential aspects:

1) Given a SoA and an $\alpha$ related to this SoA, if we say that $\alpha$ will happen in the $\mathrm{F}$, it may be inferred that $\alpha$ has not happened $>\alpha$ will be verifiable $>\alpha$ is not verifiable yet $>\alpha$ is not certain, $\alpha$ is probable, $\alpha$ is possible. ${ }^{13}$ This paves the way for the use of $\mathrm{F}$ and $\mathrm{C}$ in the expression of doubt, of conjecture, of different degrees of possibility, probability, or approximation.

2) Given a SoA and an $\alpha$ related to this SoA, if we say that $\alpha$ will happen in the F, it may be inferred that we claim this according to our own point of view $>$ it is our opinion, our belief... From dialogical and reportative context, it will pave the way for REC-type uses, inasmuch as, during interaction situations, SP/W marks his non-prise en charge (Abouda 2001) of the position expressed by the $\mathrm{AD} / \mathrm{R}$.

3) Given a SoA and an $\alpha$ related to this SoA, if we say that $\alpha$ will happen in the F, it may be inferred that $\alpha$ will happen after $>\alpha$ is a consequence of the SoA to which it is related. That explains the presence of $\mathrm{F} / \mathrm{FP}$ in calculus sequences, of logical reasoning, in conditional constructions, etc. in which it expresses the result of an evaluation of the SoA.

These theoretical approaches have proven useful in explaining the emergence of the epistemic future (EpF; Martines 2015) and, as will be seen, of the Catalan epistemic conditional (EpC) and REC. In the Romance sphere, perhaps in the evolutionary trail that must have been drawn by Late Latin, cases of EpF and EpC become scarce and, a point not yet made with sufficient emphasis, linked to specific communicative contexts. Catalan will have been no exception to this. The semantization of the Ep sense, without a reference to the F, and with a prevailing modal and evidential role, seems to have followed a process characterized by gradualness and subjectification. It starts to emerge in contexts that may aid it, still oriented towards the F, but with a clear modal and evidential value. They are contexts in the $2^{\text {nd }}$ and $3^{\text {rd }}$ person, which include subjective predictions. In general, they indicate inferential processes in which the SP/W has analyzed and assessed a specific SoA, and utters a conclusion projected towards an ulterior time; this is done according to criteria that may be subjective (interests, beliefs...), encyclopedic information, perception and categorization of reality, etc. This connection with futureness (in a present or past realm) can be gradual. We can find contexts fundamentally oriented towards a posterior time: ${ }^{14}$

13. A similar metonymic process is that which explains the change of sense in probable 'can be proven, verified' $>$ 'can exist with a degree of certainty'.

14. In Martines (2015) we have provided a detailed analysis of emergence processes for Ep values of the $\mathrm{F}$ and the $\mathrm{C}$. The reader can find the details in said articles; at present, we will limit ourselves 
(12) a. d'aquí a XV jorns, que serà lo jorn de sen Miquel (Desclot, Crònica, $13^{\text {th }}$ C. $b, \mathrm{IV}, 35)$

[from now to 15 days, that it will be Saint Michael's day]

b. Denuncià-li l'àngel Sent Gabriel que él, Zacharies, auria un fil que auria nom Joan; lo qual no beuria vi ni servea, e iria davant lo Seyor en esperit e en virtut d'Elies (Vides, $13^{\text {th }}$ C., II, p. 25)

[Saint Gabriel the angel announced to him that he, Zechariah, would have a son who would be named John; who would drink neither wine nor beer, and would go before the Lord in the spirit and virtue of Elijah]

Likewise, from ancient times we find contexts in which, besides the expression of posteriority, the F and FPC incorporate various nuances of subjectivity. These nuances are linked to specific pragmatic situations. For instance, a volitive nuance is frequent in the $1^{\text {st }}$ person when the SP/W expresses, besides futureness, his will or commitment to carry out (or not) a given action; indeed, in varying degrees: from oaths found in the eleventh century (13) to more complex texts, where one can observe the variation of nuances between the $2^{\text {nd }}$ and $3^{\text {rd }}$ persons (14-17), more closely related to prediction (Traugott \& Dasher 2002: 221-224; Narrog 2012: 171-184); it must be stressed that in cases of FPC (14), the SP/W reports in the $3^{\text {rd }}$ person the words of a different speaker, who would have spoken in the $1^{\text {st }}$ person.

(13) Juro ego Ramonde, fili Estefania, ad ti Ramonde, fili Ermesende, fideles ti seré de ista ora ad auante [...]. De esta ora ad auante non ti deceberé, ni deceber non ti faré (Feudal oath, 1035-1076; Russell 1965: 64)

[I, R., son of Stefanie, do swear to you R., son of Ermesende, that I shall be faithful to you from this time forth [...]. From this day forth I shall not deceive you, nor shall I have you deceived]

(14) Et dixit mihi Guilelm Arnall et conveng m'o che no siria a mos dons (Grievances of Guitart Isarn, 1080-1095; Russell 1965: 74)

[And Guilelm Arnall spoke to me, and agreed he would not be for my damage ('would not turn against me']

(15) [Sermon on the Temptations of Christ] Qan lo Diable vit e conog qe re d'aizò no faria $\mathrm{N}$ [ostre] $\mathrm{S}$ [èiner], portà $\cdot 1$ en la ciutad senta de Jherusalem e posà $\cdot 1$ sus e $\cdot 1$ temple (Organyà, c. 1200, 122)

[When the Devil saw, and understood that Our Lord would do none of that, he took him to the Holy City of Jerusalem and placed him on top of the temple]

to reproducing and summarizing the essential. Whenever possible, we provide new material in $\S$ 2 ; we analyze in $\S 3$, from the perspective of intersubjectification, both examples from Martines (2015) and new material. 
(16) si Déus o vol, jo us faré ganar que valga CC solidos [...], que jo faré anar lo pleit d'en Rabinat e meu en vostre poder e valrà-us bé m solidos franceses que vós haurets per bon dret de tort [...] (Letter from a priest to a bishop, 1257; Rasico 2006: 404)

[if it please God, I will make you win the worth of 200 gold coins [...], that $I$ will put mine and R.'s lawsuit in your power and it will earn you a thousand French gold coins that you will receive as a right of attack]

(17) Mas con a Milà preÿcassen mot fortment e estegessen públicament, lo sobirà bisbe, quant ó saup, se pensà que Sen Pere era hom de gran coratye: per què no auria paor de la gran multitut dels nemics (Vides, $13^{\text {th }}$ C.b. II, 431)

[But, because they preached very powerfully and were seen in public in Milan, the sovereign Bishop, in hearing of this, thought Saint Peter was a man of great courage; for this reason he would not fear the great multitude of enemies]

These cases all share an orientation towards the F: they project a SoA towards a time posterior to $\mathrm{E}$; let us note, however, that a modal volitive component is expressed in the $1^{\text {st }}$ person $\left(3^{\text {rd }}\right.$ in FPC $\left.<1^{\text {st }}\right)$ of $(13,14$ and 16$)$ : the SP/W commits himself to carrying out a given action at a later time (F o FP): he commits to being faithful and to respect the rights of his lord in (13), not to go against the interest of his lord in (14) or to conduct the lawsuit in a way that favors his own interest and those of the bishop with whom he has dealings in (16); on the other hand, in the $2^{\text {nd }}$ and $3^{\text {rd }}$ person forms of $(15,16$ and 17$)$, the SP/W predicts, views a certain SoA as possible in a future time: the fact that Christ will not fall (was not going to fall) in the first temptation (turning stones into bread) in (15), the earnings of the fighting and how much the bishop will obtain from it in (16) or the fact that Saint Peter was not going to be afraid of facing the heretics in (17). In these predictions, there is a subjective charge that combines the evidential and modal components: they are founded on $a$ ) the evaluation of the SoA, either directly (by observing Christ's behavior or through firsthand knowledge of the state of the fighting), or through reported speech (news of St. Peter's behavior); and on $b$ ) the formulation of a possibility (at a posterior time)..$^{15}$

From the end of the thirteenth century onwards, as we discover uses closer to the $\mathrm{EpF} / \mathrm{EpC}$, we also notice an increase of cases which, though oriented towards an ulterior time, display a modal nuance and marked predictive and inferential values. Subjective predictive contexts are common on which the product of an inference

15. The $\mathrm{F}$ appears frequently in the $1^{\text {st }}$ person without a volitive value, but a rather predictive value with an Ep nuance (proportional to the SP/W's reduced control over facts or states; Langacker 2009: 151, Pietrandrea 2005: 120, Sentí 2013: 141). In the following example, the SP/W deems it possible, he represents himself in a F time being capable of knowing (coneixeré) whether somebody deserves punishment; to the contrary, the volitive sense remains in combatré: «prec-vos, sènyer, que-m lexets parlar ab la emperadriu, que yo coneixeré bé en les sues paraules si mer mal en aquesta cosa; que, certes, si ela és colpable, yo no·m combatré ja per ela (Desclot, Crònica, $13^{\text {th }}$ C.b. II, 51)» [I beg you, sir, let me speak to the empress, that I shall know from her words if she deserves ill in this matter; that, to be sure, if she is guilty, I shall not fight for her still]. 
based on the evaluation of the SoA is projected upon a time that is set in the future. A fact is deemed possible at a later moment based on a speaker's own assessment. Some instances of these can be seen below.

James I discusses with his knights the strategy to conquer Valencia, and their problems with supplies. Once the situation has been analyzed, he gives his opinion:

(18) E, si aquest loch [el Puig] no·s té, València és perduda per aventura per tots temps, que jamés no·n venrem en tam bon lanç (Jaume I, Fets, $13^{\text {th }}$ C. $b, 97 r$ ) [And if this place [the Puig] is not conquered, Valencia is lost, perhaps forever, as we shall never see an occasion as good as this]

Example (18) is inserted in a speech filled with the king's reproof of some of his least cooperative allies. After a few days, the king himself believes he has found the solution to the supplies issues. The passage in (19) describes how he reaches this conclusion, which was suggested to him by the masts of the many boats he has seen anchored in Tarragona: bring them over from Mallorca; this, he explains to one of his underlings:

(19) E nós, qui entràvem en Tarragona per el cami desús de Vila-secca, vim arbres molts en Salou [...]. E dixem-li: «Ia cosa havem pensada: que creem que trobarem conseyl per al pug. Ir, quant passàvem per Vila-secca, vim arbres a Salou, e creem que hi haja conduyt [...]» (Jaume I, Fets, $13^{\text {th }}$ C.b, 97v)

[And we, who were entering Tarragona by way of the upper path of Vilaseca, we have seen many masts in Salou [...]. And we said to him: «We have thought of something: that be believe we shall find the conquest of the Puig. Yesterday, as we passed Vila-seca, we saw masts in Salou, and we believe there may be supplies there]

A boatman, who senses the gravity of the political situation, and his passengers' status, anticipates he may obtain benefits by delivering them to their enemies:

(20) Lo seyor de la barcha pensà $\cdot$ s que aquests eren honrats hòmens e que, si ó deÿa al castelà d'aquel castel, que·n auria bon gasardó d'él e, quax qui va fer leya hó sercar alre, partí·s de la barcha e anà-se·n al castelà del castel (Desclot, Crònica, $13^{\text {th }}$ C.b, II, 178)

[The owner of the boat thought these were important men and that, if he told the master of that castle, he would get a good reward from him, and the same way one might go to get lumber, or anything else, he left his boat and went to the castle's master]

Still not abandoning a perspective of ulteriority, these three cases appear rather oriented towards the SP/W inasmuch as they report his opinions and beliefs (speaker-oriented, Narrog 2012) and make explicit the evidential basis of the prediction: encyclopedic knowledge (the king has much military and political experience, knows the current strategy well (which he deems favorable to his plans of conquest) 
and the need of supplies in (18), or the direct observation of a SoA (transport-capable vessels in (19)) and his assessment based on his own perspectives, possibilities, values, interests... (the desire to make the most of the occasion delivering the noble entourage to their enemy in exchange for a reward in (20)).

Again, the $\mathrm{C}$ in place of the $\mathrm{F}$ is justified by the reported-speech type of the narration in (20). The evidential character is highlighted by the presence of verbs such as pensar 'think' or creure 'believe'.

Likewise, there are contexts in which the temporal component has been weakened even further; they reproduce a reasoning process: they present the premises that lead inferentially to a conclusion, expressed in F, in present contexts, or in C, in past contexts. It is interesting to note that these may appear in covariation with the epistemic periphrases «poder 'can'/deure 'must' + INFINITIVE» (see (21) and note 16). These are uses which are close to those observed in Late Latin as first evidence of the Ep value of F). We find them, for example, in the philosophical prose of Ramon Llull:

(21) si la umana volentat, qui és criatura spirital, ha tan gran plaser hó desplaser per odorar, que és criatura corporal, iquant molt més pot haver gran plaser per voler Déus, qui és cosa sperital! ¡Ne quant més haurà la volentat de hom peccador major desplaser en desamar Déu, que en odorar la infernal pudor! (Llull, Meravelles, III, 1288-1289, 77) ${ }^{16}$

[if human will, a spiritual creature, takes great pleasure or displeasure in smell, being a bodily creature, how much more pleasure can it have in loving God, who is spiritual matter! And how much more displeasure will it take ('must take'), the will of a sinner, in not loving God, than in breathing the stench of hell!]

(22) Mas saber Deus que es en si metex, null home no o pot saber, cor null home no pot saber sa anima metexa que és, doncs, con sabrá Déus que es? (Llull, Gentil, c. 1274/1276, 52)

[But God knowing what he is in himself, no man can ever know it, because no man can ever know what is his own soul, therefore, how will he know ('can he know') what God is?]

We have already observed that the F/FP could carry a variably marked modal and evidential charge that could prevail over the orientation towards a posterior time. These cases are interesting precisely because the orientations towards a later time has been weakened (bleaching process). Here, we have made explicit the inferential scheme within which the conclusion (necessarily posterior to the evaluation of this SoA), charged with an epistemic value, can be formulated in

16. With «deure 'must' + INF»: «Si luxúria mou lo cors a peccar, quant més membrança de la passió de Crist e de la noblea de Nostra Dona deu moure la volentat a pietat, a perdonar!» (Llull, Blaquerna, II, 1276-1283: 68) [If lust moves the body to sin, the more I remember of the Passion of Christ and the nobleness of Our Lady, it must move the will to mercy, to forgive!]. 
F (or with the epistemic periphrasis «deure 'must' + INFINITIVE» (see previous note). Thus, as has been shown so far, these appear to be instances of the basic inference (see supra inference 3)) acting to link the notion of [POSTERIORITY] to [CONSEQUENCE]: the event formulated in $\mathrm{F} / \mathrm{C}$ is perceived as a necessary possibility, derived from the given, assessed SoA. ${ }^{17}$

From the end of the thirteenth century onwards, the $\mathrm{F}$ and the $\mathrm{C}$ become more frequent in two contexts which are marked by subjectification. Rather than situating an event at a later time, the $\mathrm{F}$ and $\mathrm{C}$ (FP) forms serve to express the SP/W's attitude regarding the speech act: the SP/W either deems it possible or does not question the viability of a SoA. The link to ulteriority has not been completely broken inasmuch as there seems to be a displacement towards a moment posterior to the verification of a possible SoA (Saussure \& Morencey 2012: 209; Morency 2010, Saussure 2013); we will return to these cases below to examine them in interactional contexts.

In a passage of the Chronic of king James I, an appropriate and elevated position was sought to build a tower during the siege of a city; in his investigation, the king had found several alternatives and, in the end, he had chosen a hill. The following day, he explained:

(23) quan haguem menjat, enviam per Don Rodrigo Liçana e dixem-li: «Don Rodrigo, hojam missa maytí, que nós havem aestmat I pug que creem que serà bo a bastida» (Jaume I, Fets, $13^{\text {th }}$ C. $b, 132$ r)

[after we had eaten, we sent for Don R. L. and said to him: «Don R., let us hear an early mass, because we have studied a hill we think will be ('must be') good for a siege tower»]

The hill had already been assessed (havem aestmat) and deemed adequate by the SP/W (the king) himself. The F, reinforced by the evidential creem, serves to express the supposition ('the hill is probably appropriate'); and refers to a future verification of said assessment: when the siege tower is built, the choice will be confirmed.

We find an extensive series of similar examples in narrative contexts, with indirect interrogatives (introduced by si, qui, qual, que) that depend on verbs of knowledge or perception, on evidential verbs (encercar 'seek, discover, find out', guardar 'look, verify, know', oir 'hear', saber 'know', veure o veer 'see'...), and verbs with an Ep value; in all of those, the verification of the conjecture is deferred. For instance, in (24) the confirmation of the news' veracity will be carried out after these are heard and evaluated:

(24) E! Hoïts? Les noves d'En Guillem d'Aguiló si seran veritat? (Jaume I, Fets, $13^{\text {th }}$ C. $\left.b, 110 v\right)$

[Eh! Do you hear? The news of G., will they ('can they') be true?]

17. In $\mathrm{C}$, see (28). 
In past contexts, Cs are relatively frequent, and the most frequent in narrative texts; let us consider some. Saint Nicholas used to break nights into a neighbor's home and leave some gold to help him out; in the end, one night, this neighbor decided to stay awake to discover who this helper had to be:

(25) él perpensà a vetlar, per so que sabés qui seria aquel qui a la sua freytura avia acorregut (Vides, $13^{\text {th }}$ C. $b$, II, p. 41)

[he [the neighbor] thought to keep vigil in order to discover who it would be ('had to be') who had helped him in his hour of need]

Similarly, on this passage from the same source, the character opened her eyes to discover who it had to be that she had heard screaming (a demon!):

(26) E co Senta Juliana ubrís un poc los uls, per so que veés qui siria aquel qui disia aytals paraules, [per què] lo demoni fugí, cridan (Vides, $13^{\text {th }}$ C., II, p. 274)

[And when Saint Juliana opened her eyes slightly, to see who it would be ('had to be') who spoke those words, the demon took off, screaming]

Cases of a composite $\mathrm{C}$ are not infrequent. ${ }^{18}$ Also of interest (27), a case more closely related to the ones we will examine below in interactional contexts: a conjecture is stated in $\mathrm{C}$ with the purpose of eliciting a response in the listener. $\mathrm{A}$ woman, an elderly prostitute, had spent a long time in arduous penance: locked up, taking only bread and water and praying on her knees for three years. After assessing the hardship of her penance and divine mercy, she believes God may have forgiven her. She decides to ask the abbot who gave her this penance whether her sins could already have been pardoned: she utters a conjecture for her interlocutor to respond to:

(27) E quant ela ac estat III ayns enclausa, l'abat En Pannúcio ac compassió d'ela, per què se n'anà a l'abat qui avia nom Antoni, per so que li demanés si auria Déus perdonats los peccats en aquela dona (Vides, $13^{\text {th }}$ C.b, III, p. 344)

[And when she had spent 3 years locked up, Abbot Pannúcio had mercy on her, so he went to Abbot Antoni to ask whether God would have ['had to have'] forgiven that woman's sins]

It would be remiss if we didn't consider the following example (from Martines 2015), as it reproduces the entire inference process (see (21), in F). It is a declaration in a process. The person speaking has suffered a burglary at home: one night while he slept with his wife, he heard some men walking on the roof, and heard a falling roof tile; because of this, he inferred that the burglars would have jumped and fallen, and therefore had to be hurt. He decided to verify this:

18. Two interesting examples of this case, from Llull (Blaquerna, II, c. 1276-1283, 92 and 164), have been discussed in Martines (2015). 
(28) si per ventura aquel qui anava sobre la teulada si s'auria trencada la cama al saltar que féu e si seria assèn entorn. E posà-y la escala e pugà en lo terrat per guardar si $\cdot \mathrm{n}$ seria entorn (Cort de Cocentaina, 1277, 137)

[if by any chance the one who walked on the roof would have broken ['could have/should have broken'] his leg in the leap, and if he would be ['could/had to be'] still around. And he took a ladder and climbed up on the rooftop to see if he would be ['could/had to be'] around $]^{19}$

We end this section with (29), in the middle of the road between magnitude estimations $^{20}$ and the interactional contexts we will discuss in $\S 3$. In a dialogue on the possibility of organizing a fleet to recover the Holy Land, the pope asked how many boats he could get from the sultan at that time; after an advisor's response, the pope makes an approximate calculation of what crusaders would need:

(29) E sobre açò demanà l'apostoli quin navili poria haver lo soudà. E dix el maestre: «Sire, sí m’ajut Déus, je vi que ell mes sa punya en armar e volia assetiar Acre, e anc no poc armar mas XVII entre galees e altres llenys». Pus dix l'apostoli: «Nós n'hauriem mester atres tantes o Xx. E nós dixem-li: «Pare sant, no us cal» (Jaume I, Fets, $13^{\text {th }}$ C.b, 193r)

[And on this the pope asked what army the sultan could ['had to be able to'] have. And the master said, «My Lord, may God help me, I saw he made a great effort to raise an army and he wanted to lay siege to Acre, and could never make more than 17 galleys and ships altogether». The pope said: «We could need about as much as that, or even 20». And we said: «Holy Father, you do not need them»]

\section{Intersubjectification of the future and the future-of-the-past: the path to REC}

As we have discussed above, and as it happens in processes of semantic change, including grammaticalization, subjectification must have occurred as the Ep value of F and FP emerged. This process did not halt at this point: especially in dialogical or reported-speech context, starting in the latter part of the thirteenth century one can observe types of usage of $\mathrm{F}$ and $\mathrm{C}$ that approached intersubjectification. These uses prefigure values which, decades or centuries later, will be found semanticized in texts. Each of the aforementioned values would require a specialized analysis, and this would demand we go beyond the scope of this paper. We shall therefore limit ourselves to a presentation and highlighting of the common and anticipating traits of the REC. Namely, the concessive $\mathrm{C}$, mirative $\mathrm{C}$, conjectural $\mathrm{C}$ for response elicitation, and, lastly, the reported-context conjectural $\mathrm{C}$.

19. In the wife's declaration, parallel to the one above, we do not find the EpC: «Dix que veuria si $s$ avia trencada la cama o si jahia aly entorn» ['He said he would see if he had broken his leg or if he still lay around'].

20. On these uses, see Martines (2015). 
Like Traugott (2003: 124), ${ }^{21}$ we conceive of intersubjectification as a dynamic process of semantic change that leads to the development of markers to express the SP/W's attention «to the cognitive stances and social identities of the Addressee». This process of change may follow a scheme such as the following: «non-/less subjective > subjective > intersubjective» (Traugott 2010: 35). Already years before that notion was articulated, Traugott \& Dasher's (2002) seminal work had extensively covered intersubjectification in an analysis of the development of adverbials with discourse marker function and the development of social deictics; likewise, it covered the field of modality, which is also related to the topic at hand. It should suffice to recall one study on the expression of the intersubjective value of ought to and, conversely, the rather subjective value of should from the twentieth century onwards in dialogical contexts: the SP/W utilizes ought to while aware and accepting of whatever it is the $\mathrm{AD} / \mathrm{R}$ actually thinks, and saves should for the expression of a personal opinion. Similarly, the intersubjective use of may in contexts such as «She may jog, but she sure looks unhealthy to me» is addressed:

Here the first clause is concessive and presupposes that the interlocutor or someone has said that she runs («although she may jog, as you say...»). The speaker grudgingly accepts this, and then goes on to draw some conclusion that does no directly follow from modalized proposition. (Traugott \& Dasher 2002: 115)

Among the functions of language most apparent in the SP/W's attention to the intersubjective «face» of the $\mathrm{AD} / \mathrm{R}$, Traugott (2014: 10) cites a minimum of two: the first related to the expression of politeness, that is, the way in which SP/W acknowledges the social status of the $\mathrm{AD} / \mathrm{R} ;{ }^{22}$ and a second one related to metadiscoursive functions, such as turn-giving or elicitation of response.

More recently, Narrog (2014) has dug further into this notion of intersubjectification. He proposes a distinction among three main types of semantic change: speaker-orientation (subjectification), hearer-orientation (or intersubjectification) and textual/discourse-orientation. He revisits the English usage of the modal verb may, markedly subjective, and the fact that it has developed a concessive value. Aside from intersubjectification, Narrog explains this phenomenon by identifying a textual, or «discourse-oriented» role, such as in: «We may have our differences from time to time, but basically we trust another's judgement». Here, we can see a proposition which has been introduced by may, and in which SP/W admits the possibility ('the existence of differences') held (presumably) by the AD/R, and a second proposition which contradicts the first. The concessive construction reflects the negotiation between the SP/W and $\mathrm{AD} / \mathrm{R}$ : the protases of the concessive incorporates a proposition and a point of view (that of the $\mathrm{AD} / \mathrm{R}$ ), which stands in opposition to the assertions of the SP/W herself, which is included in the main clause; the point of view expressed in the protases may originate directly in the $A D / R$, or

21. An exposition of different conceptions of intersubjectification can be found in Nuyts (2014).

22. Despite its interest and its connection to the topics occupying us here, the analysis of the $\mathrm{C}$ of politeness or mitigation would go beyond the scope of this paper. 
it may have been inferred by the SP/W. The resulting concessive construction is «primarily textual in the sense of connecting propositions». No less interesting is the fact that Narrog (2014: 46-48) sees in the concessive may, among others, ${ }^{23} \mathrm{a}$ case of «grammaticalized polyphonic (diachronic) structures, rendering voices of two or more discourse participants» (p. 47-48).

Squartini (2012), as a prolific scholar of evidentiality, has also recently addressed the conjectural $\mathrm{F}$, the concessive $\mathrm{F}$ and the exclamative $\mathrm{F}$ in Italian. More than an epistemic modality, Squartini sees evidentiality - understood as an expression of the source (whether inferential, direct perceptions or reports) - as a basic trait to understand these uses of F. In a way similar to ours, he stresses the interactional and concessive character of $\mathrm{F}$ and, also related, of the exclamative $\mathrm{F}$. He explains these as manifestations of intersubjectivity. He works with a concept of intersubjectivity that combines Nuyts' (2001a, 2001b) approach with Traugott \& Dasher's (2002): ${ }^{24}$

Intersubjectivity can be conceived as an evidential relationship between the speaker's subjective SELF and external inputs, whereby the speaker acknowledges what external inputs provide. Due to this interactional interplay, concessivity represents a very complex cognitive procedure in which SELF and OTHER, the two basic dimensions of evidentiality (Frawley 1992), are concomitantly at work: a subjective SELF acknowledges what comes from external sources that are intersubjectively shared by other participants. [...] This interactional interplay can be considered intersubjective in Traugott and Dasher's (2002) perspective, for it involves a dynamic extension from the speaker's subjectivity to the addressee's sphere, but in also intersubjective in Nuyts' (2001a: 34-35, 2001b) sense for it is based on the interlocutor's shared and possibly also objectively perceived knowledge. (Squartini 2012: 2124)

After a review of some Catalan attestations of $\mathrm{EpF}$ and $\mathrm{EpC}$ of the thirteenth century from an interactional viewpoint, we can observe that the expression of intersubjectivity must have played a role of note. They are, as has already been alluded to above (and as we shall see again in a moment), the kind of uses that herald values which are only later fixed. The interplay of modal (epistemic) and evidential components, as well as the bleaching of the temporary component in the process of communicative interaction, seems essential to understand these initial instances of intersubjectification of F/FPC towards the REC. Indeed, Martines (2015) presents a variety of cases that show a) the bleaching of the temporal component: the F/FPC does not refer to an ulterior moment. It merely maintains a kind of temporal link to ulteriority insomuch as it «represents a future verification of a possible state of affairs in the present», in Saussure \& Morencey's (2012: 209-210) terms, formulated with regard to the well-worn example: «[The doorbell rings] That

23. Using similar parameters, Narrog (2012) presents an anlysis of cases of imperatives forming conditionals in English (p. 41-43) and imperatives forming concessive conditionals in Japanese and other languages (p. 43-45).

24. According to Nuyts (2005: 14): «An evaluation is subjective if the issuer presents it as being strictly his/her own responsibility; it is intersubjective if (s)he indicates that (s)he shares it with a wider group of people, possibly including the hearer». 
will be the postman». ${ }^{25}$ And $b$ ), as already alluded, the strengthening (Traugott 1988) of the modal component (the SP/W accepts (or doesn't accept) the possibility of a specific SoA) and the evidential component (the inference which is constructed on an evaluation of the SoA, of the information acquired through direct sources, or of the attitude which is assumed of the $\mathrm{AD} / \mathrm{R}$ ).

In (30), a passage of the Crònica by Desclot ( $\left.13^{\text {th }} \mathrm{C} . b\right)$, the king must urgently abandon the Castle of Perpignan because his life is at risk. A master builder knows of a secret, but undignified, escape (the sewer), and does not dare tell the king directly about this. So he does so indirectly, and the king misconstrues the message as a questioning of his courage and bravery. This passage is rich in discursive elements:

(30) Mestre picapedres $(\mathrm{Mp})$ : Sènyer, [...] però tot altra hom, eceptat vós, hic asageria de axir per i loch que jo sé.

[Master builder $(\mathrm{Mb})$ : Your Majesty, [...] but any other man, except yourself, would try to escape through an exit I know]

Rei $(R)$ : Com! [...], e no só yo tanbé hom de aventurar tota res com null altre? [King $(\mathrm{K})$ : What! [...], and am I not a man of danger, like any other]

$M p$ : Ver és [...], mas vergonya és de dir a tan nobla e a tan honrrat senyor com vós sóts, que isqua per aytal loch com aquell és, majorment vós qui sóts stat malalt lonch temps e encare no sóts millorat.

$[M b$ : This is true [...], but it is embarrassing to speak of this to such a noble and honorable Sir such as you, that you should leave through such a place, especially since you have been recently ill and not yet quite well]

$R$ : Quin loch és ayçò? [...]. Que fort serà perillós que no·u asaig d'axir, si null hom del món ho pot asajar; e axí dehits-me quin loch és.

[K: What place is that? [...]. How dangerous may it be that I might not cross it, if any other man in the world could do it]

$M p$ : Sènyer $[\ldots]$, quant obram lo castell, fém una aygüera que ve de la casa hon hom cuyna $[. .$.

$[M b$ : Sir, $[\ldots]$, when we built the Castle, we made a sewer that comes from the cooking room $[\ldots]]$

$R$ : ¡Bé· $m$ tenits per frèvol e per despoderat, que yo no pusca asajar ço que altre hom asage!

$[K$ : ¡I see you take me for a helpless weakling, that I could not attempt what any other man would do!] (Desclot, Crònica, $13^{\text {th }}$ C.b, IV, 87)

25. Saussure \& Morencey (2012: 209-210): «the speaker uses a future tense to refer a probable eventuality in the present (it is the postman who just rang de bell), thereby displacing the focus of a future event into the present (or conversely, projecting him/herself from the present into the future). The observable effect here is that the hearer understands the speaker's utterance as a probably calculation, thus resolving the inconsistency of the speaker manifesting an assumption about when it's obviously about the present». They regard the representation of a future verification as «an allocentric representation», that is, as one attributed to someone other than the SP/W at the moment of utterance (Saussure \& Morencey 2012: 209; Morency 2010, Saussure 2013). 
The SoA conveyed by the fearful words of the master builder leads the king, presumably a seasoned war veteran, to infer that the secret exit has to be dangerous for sure. Faced with these words, the king concedes that there may well exist such a difficult exit. However, he does not concede that this exit might be too difficult for him. In essence, the king is refusing the «frèvol e [...] despoderat» ('weak and powerless') image, that is, the suspicion of cowardice he has intuited in the builder's words. In this case, there is certainly, on the one hand, a displacement of SoA verification towards F: this is why the king demands to be shown this exit, and it will be decided later whether it is as difficult as assumed. On the other hand, it is an early example of the intersubjective and concessive character, oriented towards the AD/R and towards the text itself, according to Narrog (2012).

We find ourselves faced with an EpF; having said that, we still intuit a link to ulteriority: the situation depicted above would lead to a verification of the F, either through careful observation of the exit, or through additional information provided by the source (as is the case here).

Another royal chronicle that renders similar contexts with a comparable diversity of communicative situations was written near the end of the thirteenth century. In (31), during a battle, the king has had to depart from his closest aides and does not know how the fighting has progressed; when he sees them, he fears the worst:

(31) quan nós entram per la ost [...], En Guillem de Muntcada e·N Ramon de Muntcada $[\ldots]$ exiren-nos a recollir. E nós descavalcam e anam envés éls a peu; En Guillem de Muntcada somrís-se, e nós fom alegres, que havíem paor que no ns dixés mal; e pensam-nos que no seria tan mal con nós cuydàvem. (Jaume I, Fets, $13^{\text {th }}$ C. $b, 36 \mathrm{v}$ )

[when we joined the host [...] G. M. and R. M. [...] came out to greet us. We unmounted and them; G. M. smiled at us, and we were merry, because we were afraid he would give us bad news; and we thought to ourselves it would not be ['mustn't be'] as bad as we were thinking]

Due to the bitterness of the war, and the distance to his knights, the king feared that the fighting had been unsuccessful. The fact that Guillem de Muntcada smiled at him made him assume that things did not go as badly as he had feared. The $\mathrm{C}$ in place of $\mathrm{F}$ is required by reported speech within a narration in the past-tense. The king's assumption, we should note, is verified next: when he receives Guillem de Muntcada's smile and the other chiefs' report. We should also note that, in this case, the opposition is not between the positions of an $\mathrm{AD} / \mathrm{R}$ and a SP/W, but between the SoA initially imagined by the SP/W based upon his own assessment of the situation, and what Guillem de Muntcada's causes him to assume. The evidential source that has been accepted as possible (and later doubted) is not a report (that is inferred to be positive), but the SP/W's direct perception, as well as the assumptions that he makes based upon it. The concessive sense of the text can be expressed in the following paraphrase: «Given the battle's hardships, the SP/W had imagined the fighting had not been successful. Guillem de Muntcada's smile makes 
him suppose the fighting had to have been unsuccessful, but not as unsuccessful as the first evaluation of the SoA led him to believe».

Squartini (2012: 268) has found a link between the concessive F and the exclamative $\mathrm{F}$ in Italian (as well as in Spanish). ${ }^{26}$ It had not been observed that $\mathrm{C}$ could be used with a mirative value. We suggest it is a use directly linked with the conjectural $\mathrm{C}$ we described in $\S 2$ as well as with the intersubjective dimension of its concessive value and reportative character: the SP/W displays his surprise and rejection of the state of things reported to him by AD/R (or assumed of him).

A mirative nuance of the use of $F$ has also been suggested (Martines 2015) for two intriguing passages. In the first passage, the evidential source is the observation made of $\mathrm{AD} / \mathrm{W}$ 's behavior, and the inference it triggers in the SP/W: St. Dominic is about to be tormented, but he shows no fear: he sings merrily; the torturers, who would expect a different reaction, are amazed:

(32) quant passava per lo loc on lo cuydaren aucir, él passà aquèn ses temor, cantan alegrament. Per què éls, maravelats, dixeren: «Digues tu, no auràs paor de mort?» (Vides, $13^{\text {th }} \mathrm{C}$., III, 153)

[as he went by the place in which he was to be killed, he went without fear, singing merrily. On the face of which they said, in amazement: «Tell us, will you have ['have you'] no fear of dying?»]

In the second passage, a Christian is accused of robbery; the pagan authority in Ephesus demands he offers proof that the money is his, or inherited. They reject his arguments:

(33) éls li dixeren que no disia ver, mes que volia escapar: «¿En qual manera creyrem en tu que aquests dines sien haüts de tos parens, con la scriptura d'éls mostre que són feyts CCCLXXVII anys ha [...]? Tu, sembla que vules decebre los savis de Efesi» (Vides, $13^{\text {th }}$ C., III, 115)

[they told him he did not speak the truth, but wanted to escape: «How will we believe you ('may we believe you'), that you got this money from your parents, when the documents you provided show this happened 377 years ago [...]? It looks like you want to deceive the wise men of Ephesus»]

The three texts that follow, all of them in C, are no less interesting. First there is a passage of St. Adrian's life. The emperor has ordered the saint's incarceration for refusing to worship the pagan idols. The saint's wife, also a fervent Christian, had visited him in prison and witnessed how he lived in chains, among fiery beasts. She had taken for granted that he was being tortured, and felt happy that he would this way achieve divine grace; in fact, she had encouraged him to remain strong and true to his faith. He had announced to her that, in spite of prison and of his chains, he would visit her to let her know when he would be killed: this

26. On the mirative F in Spanish and an analysis of Squartini (2012), among other proposals, see Rodríguez (in press). 
way, she could be present during the ordeal. The wife then returned home. The following ensued:

(34) Enaprés quant Sent Adrià ausí dir lo dia de la sua passió, él anà a la sua casa per fer saber la sua passió a la sua muler. On, con ela fos fora la casa, una femna li o anà dir, dién que son marit era solt e vengut de la presó. E quant la sua muler o ausí dir, no o crehec, dién: «E qui l'auria pogut absolvre dels liguamens? Ja Déus no o vula que él ne sia absolt, ni que's sia partit dels sans!». E mentre aysò disia, un enfant seu li venc dién: «Moséyer és vengut, dona mia». On, con ela's pensés que fos fuyt al martiri, ela's plorà mot fort e quant vehé él, ela li tancà la porta [...] (Vides, $13^{\text {th }}$ C.b, III, 268) [Afterwards when Saint Adrian heard when his suffering and death would take place, he went home to let his wife know this. Because she was not in the house, a woman went to seek and tell her, saying her husband was free, come from prison. And when the wife heard her words, she did not believe it, and she said: "Who would have freed him ('could have freed him') of his chains? God forbid he were freed, or that he would have abandoned the saints!». And while she said this, a boy of hers came to tell her: «My lord is come, my lady.» Because she thought he had escaped, she cried copiously and when she saw him, she closed the door on him]

Clearly, the wife is surprised and rejects the possibility of her husband being free: she has left him in prison, tied down and expecting the day of his death. What is more: she wishes for her husband's martyrdom, because this will make him holy. She cannot conceive that anyone could have unchained him and let him go.

Also dated near the end of the thirteenth century, we find king James I's Chronic. This text abounds in dialogues with great discursive value. The king has ordered an investigation to discover who was minting new coins without his consent, and where. Within three days of investigation, micer Umbert, the judge, informs him he has discovered nothing; the king is disconcerted. The judge's information surprises the king, and he cannot believe there is nothing to find out about something as public as this matter:

(35) e [micer Umbert] dix-nos: «Seyor, què volets que façam? Que nuyla re no podem trobar, de veritat, de la moneda, qui la fa, ni on se fa». E nós dixem: «Açò com poria ésser, que tan gran fama sia de fer moneda, e que no trobem neguna veritat? Gran maraveyla és. Que les mates, si sabien parlar, ho porien dir; car entre les mates e $\cdot$ ls torrens la fan, can no troben casa on la puxen fer» (Jaume I, Fets, $13^{\text {th }}$ C.., $174 \mathrm{v}$ )

[and [micer Umbert] told us: «Your Majesty, what do you want us to do? We have been able to discover nothing true about the coin: who makes it and where it is made». And we said to him: «How could this be, that this is so well known, and that we cannot discover anything true? It is a wonder. If shrubberies could speak, they would tell us, because they do the minting among shrubberies and ravines, whenever they can't find a house in which to do it] 
We find again, in (34) and (35) in contexts in which the evidential source (the report presented by the child or the judge) stands in contrast to the assessment of the SoA the SP/W had made. The use of $\mathrm{C}$, instead of $\mathrm{F}$ (also viable in this context), in combination with the modal poder ('can'), serves to highlight the uncertainty; it stresses an essential feature and, as we may see, one shared by these uses of $\mathrm{F}$ and $\mathrm{C}$ marked by intersubjectivity: the non-assumption (nonprise en charge, Abouda 2001, Dendale 2014), and the distancing from the evidential source.

There might be a more direct connection between the mirative $\mathrm{C}$ and the clearly intersubjective conjectural C. Again, this value of $\mathrm{C}$ had not been described in Catalan until now, and it seems to coincide with the conditionnel de conjecture in French, as described in Bouvora \& Dendale (2013: 184-186) (36a and b), or the conditional dubitative mood, according to Squartini (2010: 112) (36c).

(36) a) Seriat-ce nostre professeur?

b) Il n'est toujours pas là. Auriat-il oublié le rendez-vous

c) Max seriat-il là? Je vois sa voiture

Jensen (1986: 275) had observed similar cases in Old Occitan, in which, according to this, the conditional «may serve to render notions of uncertainty or possibility [...]: Auriam los enaissi perdutz? (Appel, 9, 100) 'could we have lost them thus?'». More concretely, Jensen (1990: 353) specifies that in Medieval French and Occitan, "when appearing in an interrogative clause, the conditional may serve to render a notion of uncertainty or deliberation»; Jensen returns to the cited example in Occitan and compares it to the French: «E ion e dolreie de tanta milia hominum? (Jonas) 'should I not feel grief for so many thousands of men'».

In these cases, the $\mathrm{C}, a$ ) is only found in interrogative sentences (or indirect interrogatives), in interactional contexts, in which the SP/W presents a conjecture (or rather, a doubt, according to Squartini 2010) to a (real or fictitious) ${ }^{27} \mathrm{AD} / \mathrm{W}$, «à partir d'indices et devant expliquer un événement ou un état de choses au moyen d'une inférence (par abduction ou déduction)», b) the SP/W presents «le contenu de l'énoncé de façon prudente voire hésitante», with a weaker certainty or level of security than if it appeared in $\mathrm{F}, c)$ the interrogation seeks to provoke a reaction in the $\mathrm{AD} / \mathrm{W}$ : it aims to elicit his opinion, his own position on the matter (Bouvora \& Dendale 2013: 184-186) or to get him to confirm or deny the information (formulated as a conjecture) that is included in the SP/W's question; hence, they are within the domain of elicitation of response referred to by Traugott (2012: 10), within the sphere of intersubjectification.

Let us consider the following three early examples. In (37), a man doubts the authenticity of the stigmata found on St. Francis of Assisi's feet and hands. The man approaches the saint (represented on an image) and confronts him with three questions that reflect he doubts the stigmata are indeed authentic; these questions

27. Even the interrogative can be directed towards the SP/W himself, as an internal deliberation. 
include explanations he has thought of himself ('they are a miracle', 'they are pious imitation', or 'they are an astute antic of the friars') and compel the saint to provide an answer. This is the answer (!!) obtained:

(37) En Pola [Apúlia] fo un baró qui avia nom Roger, e pausà-sse denant la ymaya de Sent Francès e, enayxí con él estava, él se pensà dién: «¿Seria ya ver que Sent Francès resplendís per aytal miracle, o seria pietós escarniment, o seria maestria que aguessen trobada los frares?». E ayxi con él se pensava assò, sobtadament ausí un so enquaix que si una balesta trasqués un cayrel e sentísse nafrat en la mà sinestra. Mes con él no vesés forat en lo guant que portava en la mà, él se trasc lo guant de la mà e vesec en la palma gran nafra de què li ixia gran ardor, e dolor tant gran que a poc no moria (Vides, $13^{\text {th }}$ C., III, 334) [In Puglia there was a man named Roger, and he placed himself before an image of Saint Francis and, as he stood there, he thought to himself: «Would it be true that Saint Francis would shine due to that miracle, or would it be a pious imitation, or would it be an artifice found by the friars?» And as he thought this, he heard a sudden noise like a crossbow shooting, and felt a wound on his left hand. But as he could not find a breach in his glove, he removed it and saw on the palm of his hand a large wound that stung and hurt so greatly, he could have died]

In (38), a prince has nearly flogged a canon (a priest), who had accused him of injustices towards the Church. As the punishment was about be to executed, however, the prince hears the pious and wise words of the clergyman, and wonders if maybe a new age has come. In this case, we have an internal deliberation although, to be sure, it has the effect of showing the canon what change of attitude his words have effected in the prince.

(38) Molt fo maravellat lo princep de les paraules que 1 canonge dehia e per açó maná que hom no 1 açotás ni li feés mal, e dix aquestes paraules: «Temps ha estat que clergues sulien esser ergulloses e de vilanes paraules! On es açó vengut que tu has tan humils e tant devotes paraules? Seria temps vengut que humilitat e devoció se concordassen en vosaltres clergues e que nosaltres lechs ne prenguesem exempli de vosaltres? (Llull, Blaquerna, III, 1276-1283: 315) [The prince marveled immensely at the words the canon spoke, and thus commanded he should not be flogged or hurt in any way, and then he said these words: «There was a time clergymen were vain and vile in their speech! Whence come these words of yours, so humble and devoted? Would have the time come when humility and devotion return to clergymen, and we laymen should follow your example?»]

The third example (39) reproduces a conjecture made by a group of people among themselves. They pose a possibility they immediately attempt to confirm or discard. It refers to some knights who are under the emperor's orders to search for Saint Eustace. By chance, they take shelter at somebody's home who, after 
observing him, they suspect might be him. They know they can identify him by a scar on his head, and decide to test that possibility:

(39) E·ls cavalers, qui 1 guardaven, disien entre si: «Bem fort sembla aquest home N'Eustaxi. Guardem si auria una nafra en lo cap que pres en la batala e, si la y à, él és». Per què lo guarderen e veseren que él era (Vides, $13^{\text {th }} \mathrm{C}$., III, 229) [And the knights that looked at him said to each other: «This man resembles Eustace a great deal. Let us see if there would be a battle wound on his head and, if he does, it is he». So they looked and saw that it was he]

There is still another value of $\mathrm{C}$ connected to the cluster of intersubjective uses we have presented thus far. This value occurs in contexts placed somewhere between reported speech ('représentation du discurs autre', Kronning 2005) and the REC.

(40) Sent Augustí comfonia mot los iretges per so car éls preïcaven entre si que no seria pecar qui aucisia Sent Augustí, lo qual disien que era aucidor con a lop (Vides, $13^{\text {th }}$ C., III, 229)

[Saint Augustin confounded heretics enormously, as they preached among themselves that he who killed him would commit no sin, and the saint was regarded as a murderous wolf]

As we can see, a third person's words are reported in indirect speech, and these words are presented as a conjecture, an opinion expressed in $\mathrm{C}$; otherwise, it would have been expressed in the present (és 'is') (direct discourse), or imperfect tense ( $\mathrm{era}$ ' $b e$-IMPERFECT') (in reported speech). This use of C certainly seems to mark the speculative character of the reported information, rather than the fact that it has been obtained second-hand, as the prototypical REC will later indicate.

This typology seems to also apply to the following text. It is a fragment of complaints and refutations exposed by Friar Bernat to Judge Jacme Sarroca due to abuses against his livestock. The text renders the entire series of refutations exposed by the complainant as reported speech, headed by $E$ dix... 'And [he] said...'. Here too, if it weren't for Friar Bernat's epistemic use, the indicative past tense would have sufficed (v.g. fonch feyt 'was done'):

(41) E [dix lo dit frare Bernat que] si les dites bèsties hó cabana de la senyora reyna [...] près alcun dampnatge [...] no seria feyt en colpa d'ell ne dels frares del Temple (Pergamins e processos, 1298, 231)

[And [the aforementioned Friar Bernat said that] if the aforementioned beasts or livestock belonging to Her Majesty the Queen [...] suffered any harm [...] it would not have been done through himself or the friars of the Temple]

Uses such as these could function as bridging contexts (Evans \& Wilkins 2000: 550, Traugott 2012, Martines \& Montserrat 2014), inasmuch as they could favor invited inferences that would open a path towards REC. Let us consider this briefly. 
For a start, it helps to stress the polyphonic character of situations of intersubjectification considered thus far, particularly the one at hand (conjectural $\mathrm{C}$ in reported contexts). In both cases, we have:

a) The $\mathrm{SP} / \mathrm{W}_{\mathrm{L}}$ or locuteur-enonciateur (Ducrot 1984, Kronning 2005, Bres 2014) who is responsible for E. Concretely, the author of St. Augustin's biography, in the first case; and the court scrivener who takes note of the declarations, in the second case.

b) The $\mathrm{AD} / \mathrm{R}$ : the readers of the texts, in one case, who are interested in St. Augustin's life; the judge and the litigating parties, in the other.

c) $\mathrm{The} \mathrm{SP} / \mathrm{W}_{\mathrm{S}}$ or locuteur source: the heretics, in the first; Friar Bernat, in the second.

d) The words of $\mathrm{SP} / \mathrm{W}_{\mathrm{s}}$ reported by the $\mathrm{SP} / \mathrm{W}_{\mathrm{L}}$, that is, the previous utterance $e$. It is a previous utterance 1 ) that the $\mathrm{SP} / \mathrm{W}_{\mathrm{L}}$ of (40) could have heard the heretics or that, most likely, they reached him through another reported source (written or oral); and 2) that the $\mathrm{SP} / \mathrm{W}_{\mathrm{L}}$ of (41) has heard directly and written during Fria Bernat's declaration. This previous utterance $e$ is reported indirectly and introduced with a typical syntactic structure: speaking verb (preïcaven 'they preached'/dix 'he said') + completive subordinate (que 'that').

In both cases the content of $e$ is presented as an opinion, as an epistemic formulation, as a possibility that has been borrowed from the SP/W $\mathrm{W}_{\mathrm{S}}$ : in (40) the heretics believed that it could be it was not a sin to kill St. Augustin because, as they said, he was a murderer himself; in (41) Friar Bernat explains that the damage suffered by the queen's cattle (if indeed they had been suffered), had to be someone else's responsibility, and not his. This explains the use of $\mathrm{C}$. However, in both cases, the $\mathrm{SP} / \mathrm{W}_{\mathrm{L}}$ does not admit the reported conjectural interpretations as his own.

In both texts we find that 1), as we have said, there is information that the SP/ $\mathrm{W}_{\mathrm{L}}$ has borrowed from a SP/ $\mathrm{W}_{\mathrm{S}} ; 2$ ) there is propositional context not endorsed by the $\mathrm{SP} / \mathrm{W}_{\mathrm{L}}$; and 3 ) there is propositional content whose veracity still needs to be confirmed. As stated at the beginning, these are central characteristics of the REC (Dendale 2014). Now, let us observe that they are still within the syntactic patterns of reported speech, and that it is probably the communicative context what triggers in the $\mathrm{AD} / \mathrm{R}$ the inference that $\mathrm{SP} / \mathrm{W}_{\mathrm{L}}$ does not endorse the context of $e$ : one cannot expect the author of St. Augustin's biography to endorse the views of persons he himself calls heretics (!); likewise, a text that collects declarations in a court of justice cannot take these declarations for good or true until the end of the process: he must be able to distinguish between fact and opinion. Furthermore, if it is an opinion, it is not certain: it is something that must be confirmed. Recall the inferences in 1), 2) (\$2).

\section{Conclusions}

a) Conceiving the $\mathrm{F}$ and the $\mathrm{C}$ as prospective tenses, in which the temporal, modal and evidential components are conjugated, brings some significant advantages 
in explaining the diachronic process of semantic change and grammaticalization both have experienced in Catalan and in other Romance languages.

b) The origin of the Ep value of $\mathrm{F}$ and of $\mathrm{C}$ has been conditioned by a tendency towards subjectification and intersubjectification. We assume it was in the late thirteenth century, at the very earliest, when the first clear cases of EpF and EpC crystallized, cases in which the temporary component (the location of an event at a posterior time) ceases to prevail over the modal and evidential aspects: the expression of the SP/W's attitude is focalized. This attitude derives from an assessment of the SoA, from the interpretation construed based upon direct observation, reported information or inferences. Perhaps in an immediate period of time, we started noticing some uses that can be explained in the light of intersubjectification; here, we have briefly discussed the concessive $\mathrm{C}$, the mirative $\mathrm{C}$, the conjectural $\mathrm{C}$ for response elicitation, and, finally, the conjectural $\mathrm{C}$ in reported contexts. All of these seem to play a part in the dialogical or polyphonic game, the reported character of information and the non-prise en charge of the $\mathrm{SP} / \mathrm{W}$, such that they (especially the last type) anticipate the REC proper. In general, these are uses which are still linked to ambiguous communicative contexts, or bridging contexts, and to the implicatures this context triggers in the AD/R.

c) The later development of the REC, the EpF and the $\mathrm{CpF}$ in Catalan still poses many unanswered questions, especially in the light of historical data. It seems that the first evidences of REC in French and Catalan were coincidental. Why is REC not current in present Catalan, beyond academic and journalistic discourse? Why do there seem to be varieties of contemporary Catalan that do not use, or even reject as affected, the $\mathrm{EpF}$ and $\mathrm{EpC}$ ? To what extent has this development remained free from Castilian interference, or from the standard contemporary Catalan construction process? Research on old and contemporary Catalan must continue, and it must be based on corpora.

\section{References}

\section{Secondary literature}

Aaron, Jessi Elana (2007). «El futuro epistémico y la variación: gramaticalización y expresión de la futuridad desde 1600». Moenia 13: 253-274.

Abouda, Lotfi (2001). «Les emplois journalistique, polèmiques et atténuatif du conditionnel. Un traitement unitaire». In: Dendale, P. \& Tasmowski, L. (éds.). Le conditionnel en français. Metz, Université de Metz, pp. 277-294.

Aijmer, Karin (1985). «The semantic development of will». In: Fisiak, Jacek (ed.). Historical Semantics. Berlin: Mouton, pp. 11-21.

Aikhenvald, Alexandra (2003). «Evidentiality in typological perspective». In: Aikhenvald, Alexandra \& Dixon, R. (ed.). Studies in Evidentiality. Amsterdam; Philadelphia: John Benjamins Publishing Company, pp. 1-31.

Bourciez, Édouard (1910). Éléments de linguistique romane. París: Klincksieck.

Bouvora, Viara; Dendale, Patrick (2013). «Serait-ce un conditionnel de conjecture? Datation, évolution et mise en relation des deux conditionnels à valeur évidentielle». Cahiers Chronos 26: 183: 200. 
Brambilla Ageno, Franca (1965). «Sui valori modali del futuro nell'italiano antico». Rivista di Cultura Classica e Medioevale vII, 1, 3: 118-119.

Bres, Jacques (2014). «Le jeu dialogiques du futur et du conditionnel français». In: Anscombre, Jean-Claude et al. (eds.). Médiativité, polyphonie et modalité en français. Paris: Sorbonne nouvelle, pp. 19-34.

Bres, Jacques; Azzopardi, Sophie; Sarrazin, Sophie (2010). «Le conditionnel en français: énonciation, ultérorité dans le passé et valeurs modales». Faits de langues 40: 37-43.

Brinton, Laurel; Traugott, Elizabeth (2005). Lexicalization and language change. Cambridge: University Press Cambridge.

Bybee, Joan; Perkins, Revere; Pagliuca, William (1994). The evolution of grammar: tense, aspect, and modality in the languages of the world. Chicago: University of Chicago Press.

Company, Concepción (2006). «Tiempos de formación romance. II. Los futuros y condicionales», Sintaxis histórica de la lengua española, I. Mexico: Universidad Nacional Autónoma de México, pp. 347-418.

Comrie, B. (1976). Aspect. Cambridge: Cambridge University Press.

Cuenca, Maria Josep; Massip, M. Àngels (2005). «Connectors i processos de gramaticalització». Caplletra 38: 259-277.

De Hann, Ferdinand (2010). «Building a Semantic Map: Top-Down versus Bottom-Up Approaches». Linguistic Discovery 8.1: 102-117. $<$ http://dx.doi.org/10.1349/PS1.1537-0852.A.347>

Dendale, Patrick (2014). «Le conditionnel de reprise: apparition en français et traitement dans les grammaires du XVI ${ }^{\mathrm{e}}$ au XX ${ }^{\mathrm{e}}$ siècle». In: Anscombre, Jean-Claude et al. (eds.). Médiativité, polyphonie et modalité en français. Paris: Sorbonne nouvelle, pp. 243-264.

Ducrot, Oswald (1984). Le dire et le dit, Paris: Éditions de Minuit.

Evans, Nick; Wilkins, David (2000). «In the mind's ear: The semantic extensions of perception verbs in Australian languages». Language 76, p. 546-592. $<$ http://dx.doi.org/10.2307/417135>

Fleishchman, Suzanne (1982). The future in thought and language. Diachronic evidence from Romance. Cambridge: University Press Cambridge.

Frawley, William (1992). Linguistics Semantics. Erlbaum: Hillsdale, NJ.

Heine, Bernd (1995). «On the German werden future». In: Abraham, W. et al. (eds.). Discourse Grammar and Typology. Amsterdam; Philadelphia: John Benjamins Publishing Company, pp. 119-138.

Herman, József (1997). El latín vulgar. Barcelona: Ariel.

Hertzenberg, Mari Johanne (2008). Habere + infinitiv i latin. En undersøkelse av bruken og utviklingen. Masteroppgave i latin. Institutt for filosofi, idé- og kunsthistorie og klassiske språk. Universitetet i Oslo.

Hertzenberg, Mari Johanne (2012). «The use and development of habere + infinitive in Latin: an LFG approach». In: Kemenade, A. van \& Haas, N. de (ed.), Historical linguistics 2009 : Selected papers from the 19th International Conference on Historical Linguistics. Amsterdam; Philadelphia: John Benjamins Publishing Company, pp. 373-398.

Hopper, Paul; Elizabeth Traugott (1993 [2003]). Grammaticalization. Cambridge: Cambridge University Press. 
Jensen, Frede (1986). The Syntax of Medieval Occitan. Tübingen: Niemeyer.

Jensen, Frede (1990). Old French and Gallo-romance comparative Syntax. Tübingen: Niemeyer.

Kornfeld, Laura (2014). «Lecturas alternativas del futuro usos y significados de la perífrasis ir a + INFINITIVO». Translaciones, 1 (1): 8-29. <http://revistas.uncu.edu. ar/ojs/index.php/traslaciones/article/view/185/74>.

Kronning Hans (2005). «Polyphonie, médiation et modalisation: le cas du conditionnel épistémique». In: Bres, Jacques et al. (eds.). Dialogisme et polyphonie, De Boeck Supérieur, pp. 297-312.

Langacker, Ronald (2003). «Extreme subjectification: English tense and modals». In: Cuyckens, H. et al. (eds.). Motivation in Language: Studies in Honor of Günter Radden. Amsterdam; Philadelphia: John Benjamins Publishing Company, pp. 3-26.

Langacker, Ronald (2009). Investigations in cognitive grammar. Mouton de Gruyter, Berlin; New York.

Martines, Josep; Montserrat, Sandra (2014). «Subjectivació i inferència en l'evolució semàntica i en l'inici de la gramaticalització de jaquir (segles XI-XII)». Caplletra 56: $185-211$.

Martines, Josep (2013). «El verb estimar i l'amor hereós i Joan Roís de Corella. Un acostament segons la pragmàtica diacrònica». Afers 76: 717-739.

Martines, Josep (2015). « L'émergence des futurs épistémiques romans. L'exemple du catalan médiéval du XIII ${ }^{\mathrm{e}}$ siècle». In: Baranzini, Laura et al. (eds), Le futur dans les langues romanes. Berne: Peter Lang.

Morency, Patrick (2010). «Enrichissement épistémique du futur». Cahiers Chronos 21: 197-214.

Narrog, Heiko (2012). Modality, subjectivity, and semantic change: a cross-linguistic perspective. Oxford: Oxford University Press.

Narrog, Heiko (2014). «Beyond intersubjectification: textual uses of modality and mood in subordinate clauses as part of speech-act orientation». In: Brems, Lieselotte et al. (eds.). Intersubjectivity and Intersubjectification in Grammar and Discourse. Amsterdam; Philadelphia: John Benjamins, pp. 29-52.

Nuyts, Jan (2001a). Epistemic Modality. Language and Conceptualization. Amsterdam: John Benjamins.

Nuyts, Jan (2001b). «Subjectivity as an evidential dimension in epistemic modal expressions». Journal of Pragmatics 33: 383-400.

$<$ http://dx.doi.org/10.1016/S0378-2166(00)00009-6>

Nuyts, Jan (2005). «Modality: Overview and linguistic issues». In: Frawley, William (ed.). The expression of modality. Berlin; New York: Mouton de Fruyter, pp. 1-26.

Nuyts, Jan (2014). «Notions of (inter)subjectivity». In: Brems, Lieselotte et al. (eds.). Intersubjectivity and Intersubjectification in Grammar and Discourse. Amsterdam; Philadelphia: John Benjamins, pp. 53-76.

Pérez-Saldanya, Manuel (1998). Del llatí al català: Morfosintaxi verbal històrica. Valencia: Universitat de València.

Pérez-Saldanya, Manuel (2002). «Les relacions temporals i aspectuals». In: Solà, Joan (dir.), Gramàtica del català contemporani, II, pp. 2567-2662.

Pietrandrea, Paola (2005). Epistemic modality: functional properties and the Italian System. Amsterdam; Philadelphia: John Benjamins. 
Rivero (2014). «Spanish inferential and mirative futures and conditionals: An evidential gradable modal proposal». Lingua 151: 197-215. $<$ http://dx.doi.org/10.1016/j.lingua.2014.04.009>

Rodríguez Rosique, Susana (in press). «Spanish future in evaluative contexts: A case of mirativity?». eHumanista/IVITRA 7.

Saussure, Louis de; Patrick Morency (2012). «A cognitive-pragmatic view of the French epistemic future». French Language Studies 22: 207-223. $<\mathrm{http}$ //dx.doi.org/10.1017/S0959269511000445>

Saussure, Louis de (2013). «Perspectival interpretations of tenses». In: Jaszczolt, Kasia M. \& Saussure, Louis de (eds.), Time: Language, cognition and reality. Oxford: Oxford Oxford University Press, pp. 46-72.

Sedano, Mercedes (2005). «Futuro simple y futuro perifrástico en el español hablado y escrito». In: Actas del XIV congreso internacional de la Asociación de Lingüística y Filología de América Latina (ALFAL) A. Valencia-Espinoza. <http://www.mun doalfal.org/cdcongreso/cd/analisis_estructuras_linguisticas/sedano.swf $>$.

Sentí, Andreu (2013). Gramaticalització i subjectivació de la modalitat en català antic: un estudi de corpus de les perifrasis verbals $<$ deure $+\operatorname{INF}>i<$ haver (a/de) + $I N F>$, doctoral thesis, Universitat d'Alacant.

Slobbe, Bianca (2004). "Restructuring and the Development of the Romance Conditional Verb Forms». In: Blaho, Sylvia et al. (eds.). Proceedings of Console XII. Leiden: University of Leiden, pp.107-123.

Solà, Joan (dir.) (2002). Gramàtica del català contemporani, I-III. Barcelona: Empúries.

Soto, Guillermo (2008). «Sobre el llamado futuro de probabilidad. Algunas condiciones del valor modal de $-r e^{*} »$. Boletín de Filología, XLIII, 193-206.

Squartini, Mario (1999). «Riferimento temporale, aspetto e modalità nella diacronia del condizionale italiano». Vox Romanica 58: 57-82.

Squartini, Mario (2004). «Disentangling evidentiality and epistemic modality in romance». Lingua 114: 873-895.

$<$ http://dx.doi.org/10.1016/S0024-3841(03)00064-0>

Squartini Mario (2012). «Evidentiality in interaction: The concessive use of the Italian Future between grammar and discourse». Journal of Pragmatics 44, 15: 2116-2128. $<$ http://dx.doi.org/10.1016/j.pragma.2012.09.008>

Squartini, Mario (2001). «Filogenesi e ontogenesi del futuro italiano». Archivio glottologico italiano 86: 194-225.

Squartini, Mario (2009). «Evidentiality, Epistemicity, and their Diachronic Connections to Non-Factuality». In: Hansen, Maj-Britt \& Visconti, Jacqueline (eds.), Current Trends in Diachronic Semantics and Pragmatics. Emerald Group Publishing L., Bingley, pp. 211-226.

Squartini, Mario (2010). «Where mood, modality and illocution meet: the morphosyntax of Romance conjectures». In: Becker, Martin \& Remberger, Eva (eds.). Modality and Mood in Romance. New York; Berlin: De Gruyter, pp. 109-13

Thomas, Jean-François (2012). «Ultériorité dans le passé et éventualité en latin». Faits de langues 40: 13-20.

$<$ http://dx.doi.org/10.3726/431382_13>

Traugott, Elizabeth (1988). «Pragmatic Strengthening and Grammaticalization». Proceedings of the Fourteenth Annual Meeting of the Berkeley Linguistics Society, pp. 406-416. 
Traugott, Elizabeth (2003). «From subjectification to intersubjectification». In: Hickey, Raymond (ed.), Motives for Language Change. Cambridge: Cambridge University Press, pp. 124-139.

Traugott, Elizabeth (2010). «Revisiting subjectification and intersubjectification». In: Davidse, Kristin et al. (eds.), Subjectification, Intersubjectification and Grammaticalization. Berlin: De Gruyter Mouton, pp. 29-70.

Traugott, Elizabeth (2012). «Pragmatics and language change». In: Allan, K. \& Jaszczolt, Kasia M. (eds.), The Cambridge Handbook of Pragmatics. Cambridge University Press, Cambridge, pp. 549-566.

Traugott, Elizabeth (2014) «Intersubjectification and clause periphery». In: Brems, Lieselotte et al. (eds.). Intersubjectivity and Intersubjectification in Grammar and Discourse. Amsterdam; Philadelphia: John Benjamins, pp. 7-28.

Traugott, Elizabeth; Dasher, Richard (2002). Regularity in Semantic Change. Cambridge: Cambridge University Press.

Traugott, Elizabeth; Könnig, Ekkehard (1991). «The Semantics-Pragmatics of Grammaticalization Revisited». In: Traugott, E. \& Heine, B. (eds.), Approaches to Grammaticalization, II, pp. 189-218.

van der Auwera, Jan; Plungian, Vladimir. A. (1998). «Modality’s semantic map», Linguistic Typology, 2: 79-124.

$<$ http://dx.doi.org/10.1515/lity.1998.2.1.79>

Visser, F. (1969). A Historical Syntax of the English Language, part 3: First Half: Syntactical Units with Two Verbs. Brill, Leiden.

\section{Corpora and source texts}

Cartes Jaume II = Masià, Àngels (1989). Jaume II: Aragó, Granada i Marroc. Aportació documental. Barcelona: CSIC.

$\mathrm{CICA}=$ Corpus Informatitzat del Català Antic (CICA). Joan Torruella (dir.), Manuel Pérez-Saldanya; Josep Martines; texts selected by Vicent Martines. <http://cica. cat $/>$.

CIMTAC $=$ Corpus Informatitzat Multilingüe de Textos Antics $i$ Contemporanis. Josep Martines \& Vicent Martines (dirs.); M. Àngels Fuster and Elena Sánchez (adj. dirs). Alacant. ISIC-IVITRA-UA.

Cort de Cocentaina = Ponsoda, Joan (1996). El català i l'aragonés en els inicis del Regne de València segons el Llibre de Cort de Justícia de Cocentaina (1269-1265). Alcoi: Marfil.

Desclot, Bernat. Crònica, Miquel Coll (ed.). I-IV. Barcelona: Barcino, 1949-1950.

Dietaris de la Generalitat de Catalunya = Sans, Josep M. (dir.) (2007). Dietaris de la Generalitat de Catalunya X, Barcelona: Generalitat de Catalunya.

Epistolari de València II = Rubio, Agustín (1998). Epistolari de la València Medieval II. València/Barcelona. Institut Interuniversitari de Filologia Valenciana/Publicacions de l'Abadia de Montserrat.

Jaume I: Llibre dels fets del rei en Jaume, Jaume Bruguera (ed.). Barcelona: Barcino, 1991.

Llull, Ramon. Libre de Evast e Blanquerna, Albert Soler; Joan Santanach (eds.). Barcelona: NEORL, 2009.

Llull, Ramon. Llibre de Meravelles, Salvador Galmés (ed.). Barcelona: Barcino, 1931. 
Llull, Ramon. Llibre del gentil e dels tres savis. Anthony Bonner (ed). Patronat Ramon Llull, 2001.

Martorell, Joanot. Tirant lo Blanch. Albert Hauf (ed.). Valencia: Tirant lo Blanch, 2005.

Organyà = Homilies d'Organyà. Amadeu-J. Soberanas et al. (ed.). Barcelona: Barcino, 2001.

Pergamins e processos = Guinot, Enric (ed.) (2010). Pergamins, processos $i$ cartes reials:

Documentació dispersa valenciana del segle XIII. Valencia: Universitat de València.

Processos de Lleida = Farreny, M. Dolors (2014). La llengua dels processos de crims a la Lleida del segle XVI. Lleida: IEC.

Pujades, Josep Maria Casas (ed.) (1975). Dietari de Jeroni Pujades. Barcelona: Fundació Salvador Vives Casajuana.

Rasico, Philip (2006). El català antic. Girona: Universitat de Girona.

Russell, Paul (1965). Mediaeval Catalan linguistic texts. Oxford: Dolphin Book Co.

Vides = Kniazzeh, Charlotte Maneikis; Neugaard, Edward (ed.) (1977). Vides de Sants Rosselloneses. II, III, Barcelona: Fundació Salvador Vives Casajuana. 